\title{
PENINGKATAN MOTIVASI BELAJAR PESERTA DIDIK KELAS IXB SEMESTER GENAP DI SMP NEGERI 7 BATANG TAHUN PELAJARAN 2019/2020 TERHADAP MATA PELAJARAN SENI BUDAYA MELALUI PENDEKATAN APRESIASI
}

\author{
CHUCIK UBAIDAH \\ SMP NEGERI 7 BATANG \\ Jl. Tentara Pelajar No.20 Kalisalak Batang - Jawa Tengah \\ chucikubaidah@gmail.com
}

\begin{abstract}
ABSTRAK
Kita sering melihat dalam proses belajar-mengajar siswa seringkali kurang aktif, terutama dalam pembelajaran yang berhubungan dengan seni budaya. Mereka sering menyepelekan pelajaran seni budaya karena dianggap tidak menentukan kelulusan anak. Hasil pengamatan dan pengalaman selama mengajar di SMP Negeri 7 Batang, penulis merasakan bahwa kondisi seperti yang telah diungkapkan didepan benar-benar terjadi sehingga mata pelajaran seni budaya merupakan pelajaran pelengkap saja. Upaya yang penulis lakukan untuk mengatasi fenomena tersebut, melalui Motivasi belajar peserta didik, dimana siswa diberi motivasi dalam pembelajaran seni budaya dalam hal ini belajar membuat poster. Sehingga penulis mendapatkan hasil data dari penugasan siswa dari instumen prosedur dan unjuk kerja Siswa, pada Siklus 1 dengan mendapatkan ketuntasan belajar siswa mencapai 73,68\%, pada Siklus 2 mendapatkan ketuntasan belajar siswa sebesar 84,21\% dan pada Siklus 3 mendapatkan ketuntasan belajar siswa sebesar 92,11\%. Dengan demikian dari hasil tersebut bahwa pembelajaran pendekatan apresiasi cukup efektif untuk meningkatkan motivasi belajar peserta didik dibandingkan dengan kondisi awal.
\end{abstract}

Kata Kunci: Motivasi, Apresiasi, Ketrampilan

\section{PENDAHULUAN}

Mengajar merupakan suatu aktivitas mengorganisasikan atau mengatur lingkungan sebaik-baiknya dan menghubungkannya dengan anak, sehingga terjadi kegiatan belajar mengajar. Sedangkan yang dimaksud dengan pengelolaan pengajaran adalah kesanggupan atau kecakapan para guru dalam menciptakan suasana komunikatif yang edukatif antara guru dan peserta didik yang mencakup aspek kognitif, afektif dan psikomotorik sebagai upaya mempelajari sesuatu berdasarkan perencanaan sampai dengan tahap evaluasi dan tindak lanjut agar tercapai tujuan pengajaran ( Suryabrata : $1997: 19$ ).

Undang-undang No. 20 Tahun 2003 tentang sistem pendidikan nasional menyatakan bahwa pendidikan adalah usaha sadar dan terencana untuk mewujudkan suasana belajar dan proses pembelajaran agar peserta didik secara aktif mengembangkan potensi dirinya untuk memiliki kekuatan spiritual keagamaan, pengendalian diri, kepribadian, kecerdasan, akhlak mulia, serta ketrampilan yang 
diperlukan dirinya, masyarakat, bangsa dan negara. Mengacu pada Undang-undang tersebut maka para peserta didik tidak lepas dari kehadiran pendidik.

Pembelajaran yang menuntut keterlibatan siswa ini sesuai dengan Kurikulum yang berlaku pada negara Indonesia yaitu menggunakan kurikulum 2013 revisi yang menekankan pada peran aktif siswa dan guru sebagai fasilitator dalam proses pembelajaran (Kurniasih \& Sani, 2014). Pembelajaran merupakan interaksi antara guru dan siswa yang bertujuan untuk membentuk generasi muda yang lebih baik dan dapat mencapai tujuan pembelajaran (Ulfah, An'nur \& Mahardika, 2015).

Cara untuk mencapai hasil belajar yang efektif yaitu murid harus dijadikan pedoman setiap kali membuat persiapan mengajar ( Nasution, 1989 : 101 ). Cara menentukan bahan-bahan pelajaran harus berdasarkan skop dan urutan-urutan yang telah ditentukan instruksinya ( Hasan, 1994 : 109 ).

Motivasi belajar terhadap mata pelajaran seni budaya yang diberikan guru kepada anak berarti menciptakan suasana yang mendukung belajar agar dapat menggerakkan anak untuk melakukan kegiatan belajar atau ingin melakukannya, sehingga anak mempunyai kebutuhan untuk belajar seni budaya guna mencapai prestasi yang maksimal.

Dalam kegiatan belajar mengajar, seorang guru harus melakukan motivasi belajar kepada peserta didiknya. Dalam hal ini pendidik harus menyadari bahwa peserta didik akan mau belajar giat dengan harapan akan dapat memenuhi kebutuhan dan keinginan dari hasil belajarnya.

Apresiasi diartikan sebagai penghayatan dan penghargaan terhadap nilai yang terkandung di dalam hasil karya seni ( Bastomi, 1989:91 ). Kegiatan apresiasi menurut Sahman ( 1994 : 45 ) adalah perbuatan membentuk gambaran tentang sesuatu, menginterpretasi, menilai dan memberikan penghargaan. Pada dasarnya kegiatan berapresiasi pada seni adalah suatu proses penghayatan pada seni kemudian diiringi dengan penghargaan terhadap seni dan senimannya.

Berdasarkan beberapa pendapat tersebut di atas dapat disimpulkan bahwa pendekatan apresiasi merupakan kegiatan seni yang prosesnya berlangsung melalui tahapan pengamatan, pemahaman, penilaian dan penghargaan terhadap karya seni. Dalam Kamus Umum Bahasa Indonesia, motivasi diartikan dorongan yang berasal dalam diri seseorang secara sadar atau tidak sadar untuk melakukan suatu tindakan dengan tujuan tertentu (Depdikbud, 1999 : 660).

Trianto (2007) mengatakan penggunaan model pembelajaran yang tepat dapat membuat siswa untuk dapat menerima materi pelajaran dan mengikutinya secara maksimal sehingga tujuan pembelajaran dapat dicapai. Marisyah, dkk (2016) menyatakan penggunaan model inkuiri terbimbing pada siswa dapat meningkatkan hasil belajar siswa.

Mata Pelajaran Seni Budaya merupakan mata pelajaran yang kurang mendapat perhatian dari para peserta didik. Alasan klasik yang dikemukakan oleh para peserta didik antara lain karena mata pelajaran Seni Budaya tidak menentukan kenaikan ataupun kelulusan, sehingga dianggap "tidak penting" dan disepelekan. Dampaknya, peran peserta didik dalam proses belajar mengajar hanya sekedar asal mengikuti. Peserta didik menjadi malas mengikuti pelajaran, tidak mengerjakan tugas-tugas yang 
diberikan guru, bahkan mengantuk saat berlangsungnya proses belajar mengajar di kelas.

Tujuan akhir dari kegiatan belajar adalah pencapaian prestasi belajar yang meliputi ranah kognitif, afektif dan psikomotor. Prestasi belajar antara individu yang satu dengan yang lain tidak sama, hal ini karena disebabkan faktor individualisme yang berbeda-beda diantaranya faktor motivasi. Motivasi adalah dorongan pada diri seseorang yang menyebabkan ia bertindak, berbicara, berpikir dengan cara tertentu. Di dalam melaksanakan pekerjaan yang bersifat sadar, seseorang selalu didorong oleh motif tertentu baik intrinsik maupun ekstrinsik. Bila peserta didik belajar karena motif intrinsik hasilnya akan lebih baik dan sesuai dengan tujuan yang diharapkan. Hal ini sesuai dengan pendapat ( Nawawi, 1985 : 124 ) bahwa Peserta didik bersedia melakukan suatu kegiatan belajar bilamana motif yang mendorongnya cukup kuat, sebaliknya peserta didik yang tidak didorong oleh motif yang kuat akan meninggalkan atau sekurang-kurangnya tidak bergairah dalam belajar.

Seseorang yang mempunyai motivasi berprestasi akan rajin belajar, tidak pernah membolos dalam pergi ke sekolah, memperhatikan mata pelajaran, rajin mencacat, rajin mengerjakan pekerjaan rumah atau tugas, rajin mengusahakan sarana yang dibutuhkan dan rajin mengikuti kegiatan ektra kurikuler. Kaitan dengan mata pelajaran Seni Budaya dalam hal ini adalah gemar berolah seni. Peserta didik dengan antusias secara individu maupun kelompok membentuk kelompok belajar seperti membentuk sanggar lukis, sanggar tari, mengikuti kegiatan ekstra kurikuler bidang seni, sehingga luas wawasan seninya, memahami teori dan trampil serta kreatif dalam berolah seni.

Berdasarkan kenyataan tersebut di atas dalam penelitian ini penulis akan memaparkan usaha peningkatan motivasi belajar peserta didik terhadap mata pelajaran Seni Budaya melalui pendekatan Apresiasi.

Berdasarkan latar belakang masalah tersebut di atas, perumusan masalah yang akan dikaji dalam penelitian ini adalah : Apakah pendekatan apresiasi dapat meningkatkan motivasi belajar seni budaya pada peserta didik kelas IX B semester genap di SMP Negeri 7 Batang Tahun Pelajaran 2019/2020?

Penelitian dengan judul "Peningkatan Motivasi Belajar Seni Budaya Melalui Pendekatan Apresiasi Pada Peserta Didik Kelas IX B semester genap di SMP Negeri 7 Batang Tahun Pelajaran 2019/2020", mempunyai tujuan untuk mengetahui apakah pendekatan apresiasi dapat meningkatkan motivasi belajar seni budaya pada peserta didik kelas IX B semester genap di SMP Negeri 7 Batang Tahun Pelajaran 2019/2020.

Penelitian ini diharapkan dapat memberikan manfaat sebagai berikut: 1) Bagi Sekolah dapat memberikan bahan masukan untuk program penanganan motivasi belajar sebagai usaha meningkatkan prestasi peseta didik. 2) Menambah bahan bacaan atau wawasan mengenai pendekatan apresiasi sebagai upaya peningkatan motivasi belajar peserta didik terhadap mata pelajaran Seni Budaya. 3) Menambah ilmu pengetahuan serta pengalaman dalam perbaikan proses pembelajaran di kelas.

\section{METODE PENELITIAN}

Dalam melakukan penelitian, seorang peneliti dapat menggunakan penelitian berbagai macam metode sesuai dengan rancangan penelitian yang digunakan. Metode 
penelitian adalah sebagai usaha untuk menemukan, mengembangkan dan menguji kebenaran suatu pengetahuan, usaha mana yang dilakukan dengan menggunakan metode ilmiah (Sutrisno Hadi, 1987 : 4). Sedangkan menurut Ali (1985 : 39 ) dikatakan metode penelitian adalah suatu cara atau jalan untuk memahami sesuatu dengan melalui penyelidikan atau melalui suatu usaha dengan mencari bukti-bukti yang muncul sehubungan dengan masalah itu, sehingga diperoleh pemecahannya.

Dari dua pendapat tersebut di atas maka dapat disimpulkan bahwa metode penelitian adalah suatu cara untuk menemukan, mengembangkan dan menguji kebenaran suatu pengetahuan dengan mencari bukti-bukti yang muncul sehubungan dengan masalah itu sehingga diperoleh pemecahannya.

Metode penelitian ini adalah PTK (Penelitian Tindakan Kelas). Subyek penelitian ini adalah kelas IX B semester genap di SMP Negeri 7 Batang Tahun Pelajaran 2019/2020 yang berjumlah 24 peserta didik, yang terdiri dari 14 peserta didik putra dan 10 peserta didik putri. Pemilihan kelas IX B berdasarkan pertimbangan bahwa ketika diadakan pre test dan angket tentang motivasi belajar, kelas tersebut memiliki prosentase tertinggi motivasinya dibanding dengan kelas lain secara paralel.

Penelitian terdiri atas tiga siklus. Teknik pengumpulan data yang digunakan ada 2 (dua) cara yakni teknik tes dan non tes. Teknik tes digunakan pada siklus I, II dan III, untuk mengetahui peningkatan kemampuan olah seni, teknik non tes yaitu angket, observasi dan wawancara. Hal ini dilakukan untuk melengkapi beberapa kelemahan yang terdapat dalam teknik tes pada tiga siklus tersebut. Sedang alat pengumpulan data berupa butir soal tes praktek, lembar angket, lembar observasi dan pedoman wawancara.

Metode Tes Praktek. Mata Pelajaran Seni Budaya mengutamakan aspek psikomotorik sebagai alat mengukur bakat dan prestasi peserta didik, disamping aspek kognitif dan afektifnya. Peserta didik diharapkan menciptakan suatu karya seni sesuai dengan tema yang diberikan guru. Untuk mengetahui tingkat motivasinya dilengkapi dengan aspek kognitif dan afektif.

Metode Angket. Metode angket digunakan untuk mengetahui motivasi peserta didik yang berkaitan dengan kemampuan kognitif dan afektif.

Metode Observasi. Pengumpulan data dengan observasi dilakukan di dalam kelas, pada saat peserta didik mengikuti pelajaran. Kegiatan yang diamati meliputi tingkah laku dan aktivitas saat mendapat penjelasan tentang materi tertentu dan melakukan tugas yang diberikan guru.

Metode Wawancara. Pengumpulan data dengan melakukan dengan Tanya jawab atau wawancara secara langsung dengan responden. Data-data yang diperoleh baik, berupa nilai tes praktek dan hasil angket (data kuantitatif) dan data hasil observasi dan wawancara (kualitatif) divalidasi dengan trianggulasi data. Penelitian ini adalah penelitian tindakan kelas (PTK) artinya penelitian berbasis pada kelas. Penelitian ini dilaksanakan dalam bentuk proses pengkajian berdaur empat tahap yaitu : (a) merencanakan, (b) melakukan tindakan, (c) mengamati (observasi), dan (4) merefleksi. Adapun rinciannya sebagai berikut :

Tahap Perencanaan Penelitian (Planning). Kegiatan dalam perencanaan mencakup tahapan sebagai berikut : 1) Persiapan menyusun program pembelajaran, yaitu guru merumuskan tujuan yang akan dicapai dalam pembelajaran, mencari model 
pembelajaran, metode serta teknik yang sesuai dengan materi. Merancang instrumen penilaian, baik proses maupun hasil pembelajaran. 2) Menyusun program pembelajaran, yaitu menentukan alokasi waktu, memilih materi yang sesuai, merumuskan tujuan pembelajaran, menyusun scenario, dan merancang instrumen penilaian. 3) Mencoba/berlatih menggunakan scenario yang disusun agar sesuai dengan tujuan yang diharapkan.

Tahap Pelaksanaan Tindakan (Acting). Tindakan penelitian dilakukan dengan tiga siklus, sebab setelah dilakukan refleksi yang meliputi analisis dan penilaian terhadap proses tindakan, akan muncul permasalahan atau pemikiran baru, sehingga perlu dilakukan perencanaan ulang, tindakan dan pengamatan ulang serta refleksi ulang. Untuk mengetahui masalah tersebut di atas direncanakan sejumlah tindakan yang terbagi menjadi tiga siklus:

\section{Siklus I}

Pembelajaran untuk konsep gambar reklame dengan pendekatan apresiasi dilaksanakan dengan urutan langkah sebagai berikut :

Pendahuluan. 1) Memotivasi peserta didik dengan meminta peserta didik untuk menceritakan pengalaman dalam kehidupan sehari-hari tentang reklame. 2) Menyampaikan tujuan pembelajaran. 3) Mempersiapkan semua peralatan untuk keperluan pengajaran apresiasi. Peralatan pendukung yang digunakan adalah karya poster, selebaran, brosur, pesawat televisi, player VCD dan kaset CD tentang reklame. 4) Mengadakan Pre-tes.

Kegiatan Inti. 1) Menyampaikan informasi tentang langkah-langkah yang akan dikerjakan dalam pembelajaran dengan pendekatan apresiasi. 2) Mengatur tempat duduk peserta didik sedemikian rupa sehingga seluruh peserta didik dapat melihat gambar model dan gambar pada pesawat televisi yang ditempatkan di depan kelas. 3) Guru menampilkan beberapa karya reklame seperti: selebaran, brosur, poster komersial dan poster sosial serta visualisasi kegiatan reklame. Sambil mengamati dan mendengarkan, guru mengingatkan pada peserta didik agar memperhatihan dengan seksama dan mencatat hal-hal yang menarik tentang contoh karya reklame dan visualisasi pada penyajian VCD reklame. 4) Peserta didik membuat rekame yang diberikan guru 5) Guru mengadakan pelatihan lanjutan.

Penutup. 1) Memandu peserta didik menyimpulkan hasil pembelajaran. 2) Mengadakan evaluasi karya reklame yang telah diselesaikan dalam pembelajaran dan mengadakan angket. 3) Memberi penghargaan pada peserta didik kreatif dengan karya baik dan memberi tugas rumah.

\section{Siklus II}

Setelah dilakukan observasi dan refleksi, maka siklus II dilaksanakan dengan langkah sebagai berikut :

Pendahuluan. 1) Memotivasi peserta didik dengan meminta peserta didik untuk menceritakan pengalaman dalam kehidupan sehari-hari tentang manfaat reklame. 2) Menyampaikan tujuan pembelajaran.

Kegiatan Inti. 1) Menyampaikan informasi tentang langkah-langkah yang akan dikerjakan dalam pembelajaran dengan pendekatan apresiasi. 2) Guru mempersilahkan 
kepada peserta didik untuk mengamati, memahami, menilai dan memberikan penghargaan terhadap beberapa karya poster komersial dan poster sosial yang dipajang di dinding kelas. Sambil mengamati guru mengingatkan pada peserta didik agar memperhatihan dengan seksama dan mencatat hal-hal yang menarik pada karya tersebut. 3) Memberikan kesempatan kepada peserta didik untuk memilih dan memberikan tanggapan terhadap karya poster yang telah diamatinya. Peserta didik sambil mengerjakan lembar kerja peserta didik (LKS). Peserta didik yang dapat memberikan pilihan dan penilaian dengan baik dan benar diberikan stiker. 4) Memodelkan kembali kegiatan apresiasi secara kelompok. 5) Latihan membuat poster sosial lanjutan.

Penutup. 1) Memandu peserta didik menyimpulkan hasil pembelajaran. 2) Mengadakan evaluasi untuk mengapresiasi karya secara spontan pada karya yang diperlihatkan. Mengadakan angket. 3) Memberi penghargaan pada peserta didik atau kelompok yang kreatif dengan mempertunjukkan hasil karya yang terbaik.

\section{Siklus III}

Setelah dilakukan observasi dan refleksi siklus II, maka siklus III dilaksanakan dengan langkah sebagai berikut :

Pendahuluan. 1) Memotivasi peserta didik dengan meminta peserta didik untuk menceritakan pengalaman dalam kehidupan sehari-hari tentang kemudahan membuat gambar reklame. 2) Menyampaikan tujuan pembelajaran.

Kegiatan Inti. 1) Menyampaikan informasi tentang langkah-langkah yang akan dikerjakan dalam pembelajaran dengan pendekatan apresiasi. 2) Guru mempersilahkan kepada peserta didik untuk mengamati, memahami, menilai dan memberikan penghargaan secara kelompok terhadap karya poster yang dipertunjukkan. Guru mengingatkan kembali pada peserta didik agar memperhatihan dengan seksama dan mencatat hal-hal yang menarik pada karya tersebut. 3) Memberikan kesempatan kepada salah satu anggota kelompok peserta didik untuk memberikan apresiasi terhadap karya poster yang telah diamatinya. Peserta didik yang dapat memberikan apresiasi dengan baik dan benar diberikan pujian atau sanjungan. 4) Peserta didik membuat poster tentang "Narkoba".

Penutup. 1) Memandu peserta didik menyimpulkan hasil pembelajaran. 2) Mengadakan evaluasi terhadap karya poster yang telah selesai dikerjakan peserta didik. Mengadakan angket. 3) Memberi penghargaan pada peserta didik yang membuat karya terbaik. 4) Memotivasi peserta didik tentang kelebihan atau nilai positif bila memiliki kemampuan dalam bidang seni. Dengan kemampuan yang dimiliki dapat digunakan pula sebagai sarana untuk mencari nafkah.

Tahap Pengamatan (Observing). Observasi dilakukan secara kolaboratif dengan teman sejawat dengan menggunakan instrumen monitoring yang telah disiapkan. Pada setiap akhir pembelajaran peserta didik diminta tanggapan dengan cara wawancara dari beberapa peserta didik dan mengisi angket.

Refleksi (Reflecting). Setelah dilakukan tindakan, maka dilakukan analisis dari data yang ada baik data kualitatif maupun kuantitatif. Hasil analisis beserta kelebihan dan kekurangan yang ada dipakai untuk merumuskan dan menentukan tindakan selanjutnya. 


\section{HASIL DAN PEMBAHASAN}

Selama ini penulis amati dalam pembelajaran Seni Budaya di SMP Negeri 7 Batang Tahun Pelajaran 2019/2020, peserta didik menampakkan sikap yang kurang bersemangat dalam menerima pelajaran bahkan kadangkala ada beberapa peserta didik yang asal mengikuti dan cenderung pasif. Hal ini menyebabkan suasana kelas kurang kondusif, interaksi timbal balik antara guru dan peserta didik tidak terjadi dengan optimal dan pada akhirnya prestasi belajar Seni Budaya peserta didik SMP Negeri 7 Batang belum sesuai dengan harapan.

Sesuai jadwal, pelajaran Seni Budaya di kelas IX B setiap hari Jum' at pada jam ke 4-5. Sesuai program pembelajaran Kurikulum 13 di SMP Negeri 7 Batang Tahun Pelajaran 2019/2020 untuk mata pelajaran Seni Budaya diberikan materi Seni Rupa dan Seni Tari. Sebelum implementasi tindakan dimulai terlebih dahulu diadakan tes awal dengan bentuk soal praktek dengan 2 butir soal. Hasil tes awal ini dari 35 peserta didik yang mengikutinya, rata-rata daya serap yang dicapai hanya 28,94 \% dengan prosentase ketuntasan belajar 36,84 \%. Hal tersebut menunjukkan sebagian besar peserta didik $(63,16 \%)$ memang belum menguasai kompetensi motorik. Hasil angket dari 38 peserta didik, terdapat 3 atau 7,89\% memiliki motivasi rendah, 18 peserta didik atau 47,37\% memiliki motivasi kurang, 13 peserta didik atau 34,21\% memiliki motivasi sedang dan 4 peserta didik atau 10,53\% memiliki motivasi tinggi.

\section{Deskripsi Siklus I}

Pembelajaran untuk kompetensi dasar gambar reklame dengan pendekatan apresiasi dilaksanakan dengan urutan langkah sebagai berikut : (1) Memotivasi peserta didik dengan meminta peserta didik untuk menceritakan pengalaman dalam kehidupan sehari-hari tentang reklame, (2) Menyampaikan tujuan pembelajaran, (3) Mempersiapkan semua peralatan untuk keperluan pengajaran apresiasi. Peralatan pendukung yang digunakan adalah karya poster, selabarn, brosur, pesawat televisi, player VCD dan kaset CD tentang reklame, (4) Mengadakan Pre-tes, (5) Menyampaikan informasi tentang langkah-langkah yang akan dikerjakan dalam pembelajaran dengan pendekatan apresiasi, (7) Mengatur tempat duduk peserta didik sedemikian rupa sehingga seluruh peserta didik dapat melihat gambar model dan gambar pada pesawat televisi yang ditempatkan di depan kelas, (8) Guru menampilkan beberapa karya reklame seperti: selebaran, brosur, poster komersial dan poster sosial serta visualisasi kegiatan reklame. Sambil mengamati dan mendengarkan, guru mengingatkan pada peserta didik agar memperhatihan dengan seksama dan mencatat hal-hal yang menarik tentang contoh karya reklame dan visualisasi pada penyajian VCD reklame, (9) Peserta didik membuat rekame yang diberikan guru, (10) Guru mengadakan pelatihan lanjutan, (11) Memandu peserta didik menyimpulkan hasil pembelajaran, (12) Mengadakan evaluasi karya reklame yang telah diselesaikan dalam pembelajaran dan mengadakan angket, (13) Memberi penghargaan pada peserta didik kreatif dengan karya baik dan memberi tugas rumah.

Dalam pembelajaran ini, peserta didik diajak untuk bersama-sama mengamati, menghayati, menilai dan memberikan tanggapan atau penghargaan terhadap karya. 
Dengan bantuan guru peserta didik diajak megingat kembali unsur-unsur dan prinsip seni sebagai acuan dasar dalam menilai suatu karya seni.

Saat kegiatan ini berlangsung, tercipta suasana pembelajaran yang hidup karena tiap peserta didik mengamati dan berusaha menganalisis hasil karya orang lain. Pembelajaran ini juga menjadikan peserta didik senang dan bersemangat dalam mengikuti pembelajaran. Lebih-lebih peserta didik yang mendapat contoh karya yang baik. Dengan teknik analisis sederhana peserta didik dapat menyelesaikan kegiatan ini dengan baik dan lancar. Setelah menganalisis karya, selanjutnya peserta didik diberi tugas untuk membuat reklame dari inspirasi karya yang telah diapresiasi. Pembelajaran ini juga menyebabkan perubahan cukup menonjol pada peserta didik menyangkut motivasi belajar yang ditunjukkan dalam keaktifan peserta didik dalam belajar dibandingkan keadaan sebelumnya. Selama tindakan berlangsung, terdapat hambatanhambatan antara lain : 1) Peserta didik belum menggunakan waktu secara baik. Peserta didik lebih banyak mengamati karya tidak terfokus. 2) Ada beberapa peserta didik yang belum maksimal dalam penguasaan konsep unsur dan prinsip seni dan ada beberapa peserta didik tidak memiliki catatan mengenai hal tersebut. Maka dalam pembelajaran ke depan peserta didik memiliki diktat materi pelajaran agar peserta didik dapat memiliki acuan belajar. Disamping itu, ke depan peserta didik disediakan lembar kerja peserta didik (LKS) agar kegiatan lebih maksimal.

Pada akhir siklus I, peserta didik diminta memberi komentar tentang pembelajaran yang telah dilakukan dengan menggunakan angket dan observasi. Dari hasil angket ini, diketahui 6 peserta didik memiliki motivasi tinggi atau (15,79\%), 18 peserta didik memiliki motivasi sedang atau (47,37\%) sisanya 14 peserta didik memiliki motivasi kurang atau (36,84\%). Hasil observasi dari kolaboratorpun lebih dari $63,16 \%$ peserta didik menyatakan senang dan

sangat senang untuk mengikuti pembelajaran ini dan 36,84\% peserta didik menyatakan biasa-biasa saja. Sedang hasil tes praktek dari 35 peserta didik yang mengikuti memiliki rata-rata daya serap 60,52 \% dengan ketuntasan belajar mencapai 73,68 \%.

\section{Deskripsi Siklus II}

Dari hasil refeksi pada siklus I, maka tindakan yang dilakukan dalam siklus II ini meliputi : (1) Memotivasi peserta didik dengan meminta peserta didik untuk menceritakan pengalaman dalam kehidupan sehari-hari tentang manfaat reklame, (2) Menyampaikan tujuan pembelajaran, (3) Menyampaikan informasi tentang langkahlangkah yang akan dikerjakan dalam pembelajaran dengan pendekatan apresiasi, (4) Guru mempersilahkan kepada peserta didik untuk mengamati, memahami, menilai dan memberikan penghargaan terhadap beberapa karya poster komersial dan poster sosial yang dipajang di dinding kelas. Sambil mengamati guru mengingatkan pada peserta didik agar memperhatihan dengan seksama dan mencatat hal-hal yang menarik pada karya tersebut, (5) Memberikan kesempatan kepada peserta didik untuk memilih dan memberikan tanggapan terhadap karya poster yang telah diamatinya. Peserta didik sambil mengerjakan lembar kerja peserta didik (LKS). Peserta didik yang dapat memberikan pilihan dan penilaian dengan baik dan benar diberikan stiker, (6) Memodelkan kembali kegiatan apresiasi secara kelompok, (7) Latihan membuat reklame dengan membuat poster sosial lanjutan, (7) Memandu peserta didik 
menyimpulkan hasil pembelajaran, (8) Mengadakan evaluasi untuk mengapresiasi karya secara spontan pada karya yang diperlihatkan, (9) Mengadakan angket, (10) Memberi penghargaan pada peserta didik atau kelompok yang kreatif dengan mempertunjukkan hasil karya yang terbaik.

Pada akhir siklus II ini diketahui: 2 peserta didik atau 5,26 \% memiliki motivasi sangat tinggi, 5 peserta didik atau 21,05\% memiliki motivasi tinggi, 10peserta didik atau $42,10 \%$ memiliki motivasi sedang dan 9 peserta didik atau 31,57\% memiliki motivasi kurang. Hasil observasi dan wawancara kolaborator terdapat 78,94 \% menyatakan sangat senang dan senang serta terlibat aktif mengikuti pembelajaran ini dan $21,05 \%$ peserta didik menyatakan biasa-biasa saja. Hal ini merupakan peningkatan dari kegiatan pada siklus I. Perhatikan grafik motivasi dan tanggapan peserta didik terhadap pembelajaran yang dilakukan berikut :

Grafik 1. Motivasi Peserta didik Terhadap Pembelajaran

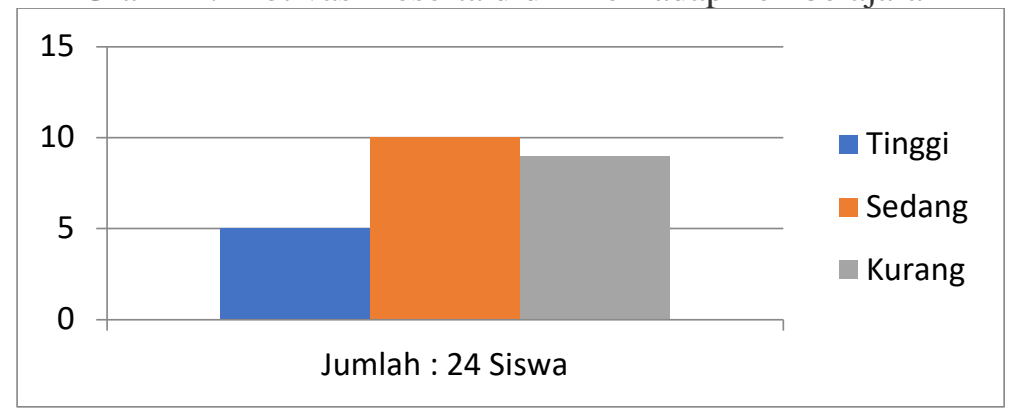

Grafik 2. Tanggapan Peserta didik Terhadap Pembelajaran

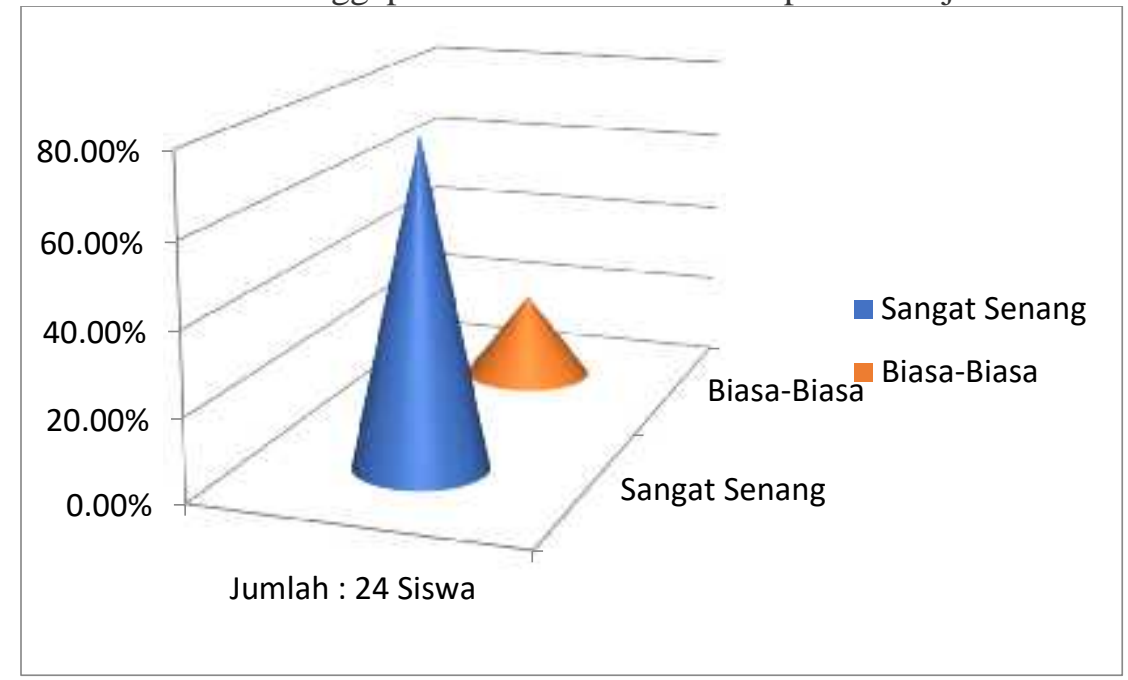

Hambatan yang masih muncul pada siklus II ini, diantaranya : 1) Masih ada beberapa peserta didik yang belum maksimal dalam belajar. 2) Peserta didik yang ditunjuk untuk menyampaikan pendapat masih main tunjuk, dan kurang percayadiri.

Hasil karya poster pada akhir siklus ke-II ini meningkat dibandingkan dengan hasil yang dicapai pada siklus ke-I. Dari 24 peserta didik yang mengikuti, rata-rata daya serap mencapai 65,78 \% dengan ketuntasan belajar 81,57\%. Hasil observasi 
kolaborator menggunakan lembar pengamatan diperoleh hasil bahwa sebagian besar peserta didik $(84,21 \%)$ telah melakukan kegiatan sesuai dengan prosedur / langkahlangkah yang diberikan dalam mengapresiasi dengan acuan unsur dan prinsip seni dengan baik dan benar. Hanya ada beberapa peserta didik $(15,79 \%)$ yang belum sesuai prosedur yang diharapkan. Ini disebabkan, tidak memiliki sarana dan reverensi yang lengkap.

\section{Deskripsi Siklus III}

Setelah dilakukan observasi dan refleksi siklus II, maka siklus III dilaksanakan dengan langkah sebagai berikut : (1) Memotivasi peserta didik dengan meminta peserta didik untuk menceritakan pengalaman dalam kehidupan sehari-hari tentang kemudahan membuat gambar reklame, (2) Menyampaikan tujuan pembelajaran, (3) Menyampaikan informasi tentang langkah-langkah yang akan dikerjakan dalam pembelajaran dengan pendekatan apresiasi, (4) Guru mempersilahkan kepada peserta didik untuk mengamati, memahami, menilai dan memberikan penghargaan secara kelompok terhadap karya poster yang dipertunjukkan. Guru mengingatkan kembali pada peserta didik agar memperhatihan dengan seksama dan mencatat hal-hal yang menarik pada karya tersebut, (5) Memberikan kesempatan kepada salah satu anggota kelompok peserta didik untuk memberikan apresiasi terhadap karya poster yang telah diamatinya. Peserta didik yang dapat memberikan apresiasi dengan baik dan benar diberikan pujian atau sanjungan, (6) Peserta didik membuat salah satu jenis reklame yaitu membuat gambar poster tentang "Narkoba", (7) Memandu peserta didik menyimpulkan hasil pembelajaran,(8) Mengadakan evaluasi terhadap karya poster yang telah selesai dikerjakan peserta didik, (9) Mengadakan angket, (10) Memberi penghargaan pada peserta didik yang membuat karya terbaik, (11) Memotivasi peserta didik tentang kelebihan atau nilai positif bila memiliki kemampuan dalam bidang seni. Dengan kemampuan yang dimiliki dapat digunakan pula sebagai sarana untuk mencari nafkah. Memberikan beberapa contoh figur seniman yang sukses seperti; Affandi, Amri Yahya, Amang Rahman dan seniman lokal Gus Sailendra dan Lucia Hartini.

Pada akhir siklus III ini diketahui: 3 peserta didik atau 7,89\% memiliki motivasi sangat tinggi, 7 peserta didik atau 26,32 \% memiliki motivasi tinggi, 10 peserta didik atau 39,47\% memiliki motivasi sedang dan 4 peserta didik atau 26,32\% memiliki motivasi kurang. Hasil observasi dan wawancara kolaborator ditemukan 92,11\% menyatakan sangat senang dan senang, terlibat aktif, dan kreatif mengikuti pembelajaran dan hanya 7,89\% peserta didik menyatakan biasa-biasa saja, kurang aktif dan tidak kreatif. Hal ini menunjukkan peningkatan dari kegiatan pada siklus I.dan II. Perhatikan grafik motivasi dan tanggapan peserta didik terhadap pembelajaran yang dilakukan berikut : 
Grafik 3. Motivasi Peserta didik Terhadap Pembelajaran

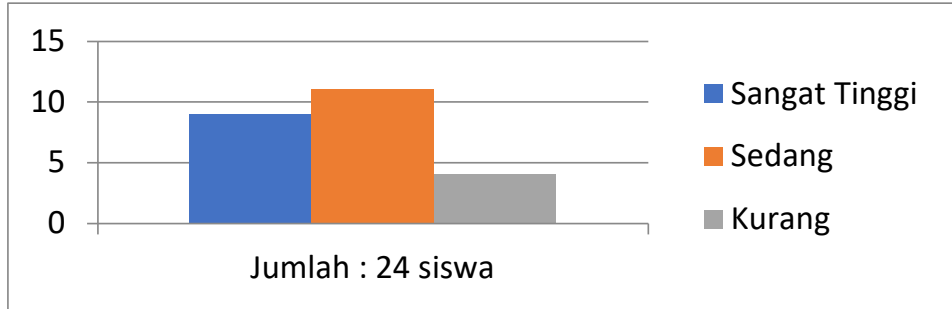

Grafik 4.Tanggapan Peserta didik Terhadap Pembelajaran

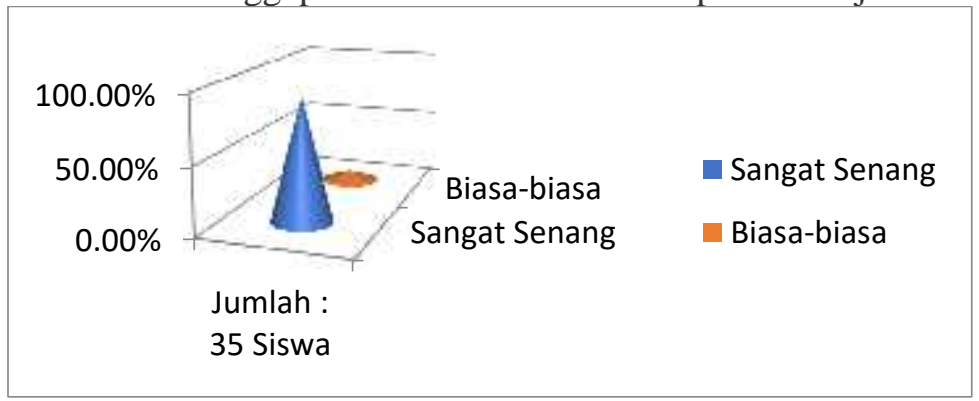

Hasil karya reklame dengan membuat poster tema "Narkoba" pada akhir siklus ke-III ini sangat meningkat dibandingkan dengan hasil yang dicapai pada siklus ke-I dan ke-II. Dari 24 peserta didik yang mengikuti, rata-rata daya serap mencapai 76,32 $\%$ dengan ketuntasan belajar $86,84 \%$. Demikian pula hasil observasi kolaborator menggunakan lembar pengamatan diperoleh hasil bahwa sebagian besar peserta didik $(89,47 \%)$ telah melakukan kegiatan apresiasi karya seni dengan baik dan benar. Hanya ada sebagian kecil peserta didik $(10,53 \%)$ yang belum sesuai harapan. Ini disebabkan kurang aktif dalam menganalis materi pembelajaran.

Dari uraian hasil penelitian di atas tampak hasil angket motivasi peserta didik dari pra siklus, siklus I, siklus II dan siklus III dan tanggapan peserta didik, serta hasil pembelajaran dari siklus I, II dan siklus III, ditunjukkan dalam tabel berikut :

Tabel 1 : Hasil Angket Motivasi Belajar Peserta didik

\begin{tabular}{|c|c|c|c|c|}
\hline Kriteria & Pra Siklus & Siklus 1 & Siklus 2 & Siklus 3 \\
\hline Sangat Tinggi & 0 & 0 & $5,25 \%$ & $7,89 \%$ \\
\hline Tinggi & $10,53 \%$ & $15,79 \%$ & $21,05 \%$ & $26,32 \%$ \\
\hline Sedang & $34,21 \%$ & $47,37 \%$ & $42,1 \%$ & $39,47 \%$ \\
\hline Kurang & $47,37 \%$ & $36,84 \%$ & $31,57 \%$ & $26,32 \%$ \\
\hline Sangat Kurang & $7,89 \%$ & 0 & 0 & 0 \\
\hline
\end{tabular}


Dari tabel hasil angket di atas, terlihat pada kategori motivasi sangat tinggi terdapat $5,26 \%$ pada siklus II dan meningkat $2,63 \%$ menjadi $7,89 \%$ pada siklus III, kategori motivasi tinggi terdapat kenaikan 5,26\% menjadi $15,79 \%$ pada siklus I, meningkat 5,26 \% menjadi $21,05 \%$ pada siklus II dan naik 5,27 \% menjadi 26,32 \% pada siklus III, dan terdapat penurunan pada kategori motivasi kurang menurun 10,53 $\%$ menjadi 36,84 \% pada siklus I, menurun 5,27 \% pada siklus II dan menurun 5,25\% pada siklus III dan tidak dijumpai lagi motivasi sangat kurang pada siklus I, siklus II dan siklus III. Hal ini menunjukkan adanya peningkatan motivasi belajar peserta didik yang cukup berarti dari pra siklus, perlakuan siklus I, siklus II, dan siklus III. Gambaran peningkatan motivasi peserta didik tersebut dapat pula dilihat dari peningkatan grafik berikut:

Grafik 5. Motivasi Peserta didik Terhadap Pembelajaran

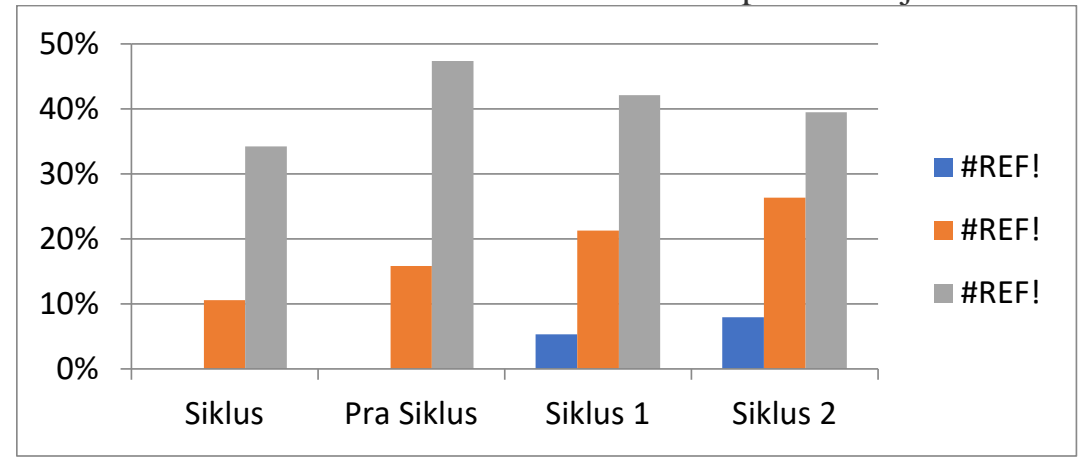

Tabel 2.Tanggapan Peserta Didik Terhadap Pembelajaran

\begin{tabular}{|l|c|c|c|}
\hline \multicolumn{1}{|c|}{ Kriteria } & Siklus 1 & Siklus 2 & Siklus 3 \\
\hline Sangat Senang & $15,79 \%$ & $21,05 \%$ & $39,47 \%$ \\
\hline Senang & $47,37 \%$ & $57,89 \%$ & $52,63 \%$ \\
\hline Cukup Senang & $26,31 \%$ & $21,5 \%$ & $7,89 \%$ \\
\hline Kurang Senang & $10,53 \%$ & 0 & 0 \\
\hline Tidak senang & 0 & 0 & 0 \\
\hline
\end{tabular}

Dari tabel hasil observasi dan wawancara kolaborator di atas, terlihat pada peserta didik yang menyatakan senang dan sangat senang, serta aktif untuk mengikuti pembelajaran ini terdapat $63,16 \%$ pada siklus I meningkat $15,78 \%$ menjadi $78,94 \%$ pada siklus II dan naik 13,17 \% menjadi 92,11 \% pada siklus III. Di samping itu terdapat $36,84 \%$ pada siklus I, menurun $15,79 \%$ menjadi $21,05 \%$ pada siklus II dan menurun $13,16 \%$ menjadi $7,89 \%$ pada siklus III, peserta didik menyatakan biasa-biasa saja dan kurang aktif dalam mengikuti pembelajaran. Hal tersebut menunjukkan 
adanya peningkatan motivasi, partisipasi dan peran aktif serta kreativitas peserta didik dalam pembelajaran. Peningkatan tersebut dapat dilihat pada grafik tanggapan peserta didik berikut:

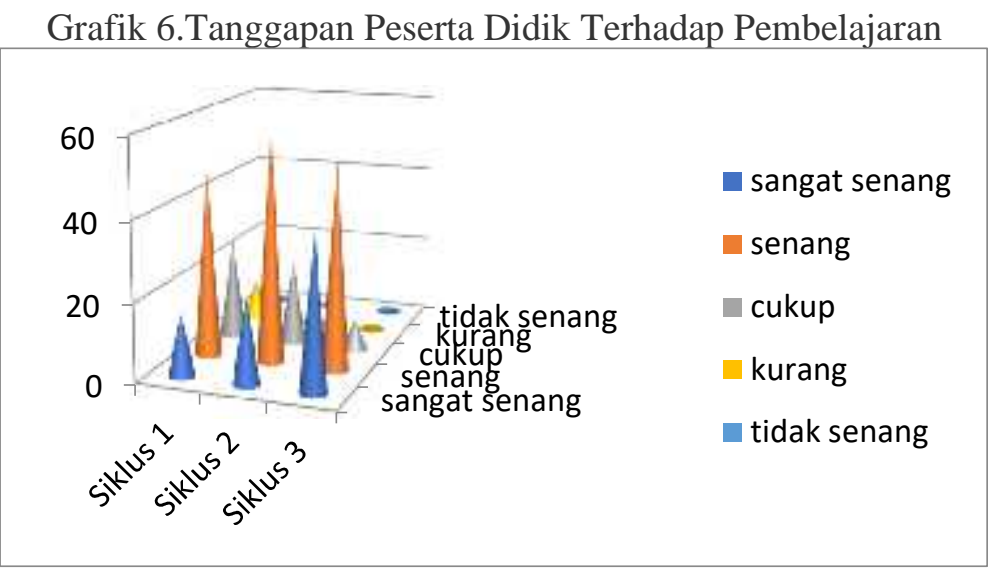

Grafik 7. Rekapitulasi daya serap dan ketuntasan belajar peserta didik

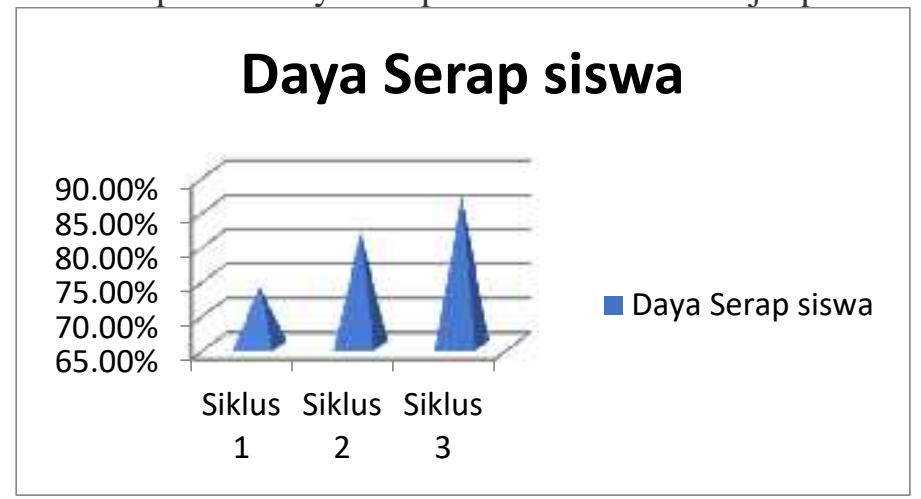

Dari tabel hasil rekapitulasi daya serap dan ketuntasan belajar peserta didik di atas, terlihat pada hasil tes praktek dari 24 peserta didik yang mengikuti memiliki ratarata daya serap $60,52 \%$ pada siklus I, meningkat $5,26 \%$ menjadi $65,78 \%$ pada siklus II, dan naik 10,54 \% menjadi 76,32 \% pada siklus III. Di samping terdapat pencapaian ketuntasan belajar 73,68 \% pada siklus I, meningkat 7,89 \% menjadi $81,57 \%$, dan naik $5,27 \%$ menjadi 86,84 \% pada siklus III. Hal ini menunjukkan dari perlakuan siklus I, siklus II dan siklus III, terdapat adanya peningkatan prestasi belajar peserta didik pada mata pelajaran Seni Budaya.

Menurut pedoman laporan hasil belajar SMP Kurikulum 13, yaitu seorang peserta didik dianggap tuntas belajar apabila daya serap minimal mencapai $75 \%$, sedang klasikal dianggap tuntas belajar apabila $85 \%$ dari jumlah peserta didik dalam kelas mempunyai daya serap minimal $75 \%$.

Jika hasil penelitian ini dibandingkan dengan indikator keberhasilan di atas, maka secara kuantitas hasil pembelajaran dengan pendekatan apresiasi ini memiliki kecenderungan hasil yang baik. Hal ini dapat dilihat dari pencapaian daya serap dan ketuntasan belajar peserta didik yang cenderung meningkat. Berarti, pembelajaran menggunakan pendekatan apresiasi dapat dikatakan cukup efektif dan berhasil. 
Dari uraian di atas dapat disimpulkan bahwa pembelajaran dengan pendekatan apresiasi pada konsep gambar reklame, dapat meningkatkan motivasi belajar peserta didik kelas IX B semester genap di SMP Negeri 7 Batang Tahun Pelajaran 2019/2020 terhadap mata pelajaran Seni Budaya, yang pada akhirnya meningkatkan pula prestasi belajar dalam mata pelajaran Seni Budaya. Hal ini ditunjukkan dari peningkatan motivasi belajar dan tanggapan peserta didik yang dapat dilihat dari partisipasi, peran aktif, dan kreativitas dalam mengikuti proses pembelajaran. Di samping itu ditunjukkan pula dengan peningkatan nilai praktek gambar reklame dan prosentase ketuntasan belajar secara klasikal, serta mampu mengapresiasi karya orang lain dengan baik dan benar.

\section{KESIMPULAN}

Simpulan penelitian ini bahwa pembelajaran menggunakan pendekatan apresiasi cukup efektif untuk meningkatkan motivasi belajar peserta didik. Indikator ini dapat dilihat dari tanggapan dan keaktifan, serta kreativitas peserta didik selama mengikuti pembelajaran, serta pencapaian daya serap dan ketuntasan belajar yang cenderung meningkat.

Saran dari hasil penelitian ini penulis menyarankan : 1) Pembelajaran dengan pendekatan apresiasi ini dapat diterapkan pada suasana kelas lain dan sekolah lain yang memiliki masalah yang cenderung sama. 2) Perlu penelitian lebih lanjut tentang pembelajaran langsung dengan pendekatan apresiasi pada konsep/ kompetensi dan subyek lain, di luar pengetahuan prosedural.

\section{DAFTAR PUSTAKA}

Bastomi, Suwadji, 1989. Wawasan Seni. IKIP Semarang Press.

Depdikbud, 1999. Petunjuk Umum Pelaksanaan Kurikulum SLTP 1994. Jakarta : Bagian Proyek Pengedaan Sarana dan Peningkatan Mutu Pendidikan Menengah Umum.

Hadari Nawawi, 1987, Metode Penelitian Bidang Sosial, Gajah Mada University, Yogyakarta Press.

Hasan, M 1994, Strategi Penelitian Pendidikan, Bandung, Angkasa.

Kurniasih, I \& Sari. (2014). Implementasi kurikulum konsep \& penerapan. Surabaya: Kata Pena.

Marisyah, dkk.(2016). Meningkatkan keterampilan proses sains dan hasil belajar siswa pada pelajaran ipafisika kelas viii b smpn 24 banjarmasin melalui model inkuiri terbimbing. Berkala Ilmiah Pendidikan Fisika, 4(1), 52.

Sahman, Humar, 1994. Estetika. IKIP Semarang Press.

S. Nasution, 1989, Didaktik Azas-azas Mengajar, Bandung, Hermans.

Trianto. (2010). Model Pembelajaran Terpadu dalam Teori dan Praktek. Jakarta: Prestas Pustaka.

Ulfah, An'nur\& Mahardika. (2015). Hubungan antara minat dan motivasi dengan hasil belajaR fisika siswa kelas x sman 10 banjarmasin. Berkala Ilmiah Pendidikan Fisika, 3(2), 146-153.

Undang-undang Republik Indonesia Nomor 20 Tahun 2003, tentang Sistem Pendidikan Nasional. 